\title{
The Role of State Attorney in Returning The State Loss Against The Heritage of Criminal Actors of Corruption Through Indonesian Civil Law (Judgment Study Number 4/Pdt.G/2017/Pn Kbu)
}

\author{
Yulia Kusuma Wardani ${ }^{1}$, Torkis Lumban Tobing ${ }^{2}$, Nanda Kurnia Pradana ${ }^{3}$ \\ \{yulia.kusumawardani@fh.unila.ac.id ${ }^{1}$, torkistobing@gmail.com², nandakp.fhunila@gmail.com ${ }^{3}$ \} \\ Universitas Lampung, Indonesia ${ }^{1}$, Universitas Lampung, Indonesia ${ }^{2}$, Universitas Lampung, Indonesia ${ }^{3}$
}

\begin{abstract}
Corruption in Indonesia is an act that is detrimental to state finances and, at the same time, damages the nation's morals. Perpetrators of criminal acts of corruption must be criminally responsible. The demand for the return of state finances by the Public Prosecutor is not stopped even though the corruption suspect dies. However, the legal process continues with filing a civil suit by the State Attorney against the suspect's heir. As in the case in Kotabumi, the North Lampung District Attorney with a superior power of attorney gave powers to several prosecutors to carry out their duties as State Attorneys to sue the heirs of the late Amiruddin Is, S.E., who was a suspect in a corruption case. This case has permanent legal force with the Kotabumi District Court Decision Number: 4/Pdt.G/2017/PN Kbu. The study in this article will focus on the powers and roles of State Attorneys and State Attorneys in Indonesia by analyzing the District Court Decision. This type of research is normative-empirical research with descriptive research type. The approach to the problem used is the applied normative (applied law approach). The data used are primary data and secondary data sourced from primary and secondary legal materials. Data analysis using qualitative analysis. The research and discussion results show that the State Attorney General's authority to sue the heirs of the perpetrators of corruption is regulated in Article 30 of the Constitution on the Attorney General's Office Jo. Article 32, and Article 33 of the PTPK Act. In the realm of private law, the prosecutor has a role as a state lawyer who represents the state outside and inside the court, both as plaintiff and defendant. As a plaintiff, the State Attorney General at the North Lampung District Prosecutor's Office succeeded in proving an illegal act committed by the late Amiruddin Is, S.E., so that the state's losses could be returned. The execution of civil decisions Number: 4/Pdt.G/2017/PNKbu is not carried out by the State Attorney but by the court through bailiffs.
\end{abstract}

Keywords: State Attorney, Lawsuit, Inheritance, Corruption

\section{Introduction}

Corruption in Indonesia has become an act that is detrimental to state finances and destroying the nation's morale. These acts of corruption have an impact on hampering the country's economy and development. Conceptually corruption is a person's deviant behavior outside of ethics, morality, tradition, law, and legal policies. In contrast, the meaning of corruption is rottenness, ugliness, immorality, dishonesty, bribery, and, immorality, deviation from holiness, words, derogatory or slanderous words [1]. The definition of corruption, according to Constitution Number 31, the Year 1999 Jo. Constitution Number 20 of 2001 concerning the Eradication of 
Corruption (PTPK Act) is an act of enriching oneself or another person or a corporation against the law which harms state finances or the country's economy [2].

Perpetrators of criminal acts of corruption must be criminally responsible. The demand for the public prosecutor's return of state finances was not stopped even though the corruption defendant died. However, the legal process was continued with filing a civil suit by the state attorney against the defendant's heir. Specific provisions, civil liability for perpetrators of criminal acts of corruption are regulated in Article 32, Article 33, and Article 34 of the PTPK Act.

Article 33 of the PTPK Act states that if a suspect dies during the investigation, while there has been a loss of state finances, the investigator will immediately submit the case files resulting from the investigation to the State Attorney or submitted to the injured agency to file a civil suit against the heir.

Prosecutors as State Attorneys are prosecutors with special powers acting for and on behalf of the state or government in carrying out the duties and powers of the prosecutor's office in the city and state administration sector. [4] The authority of the state attorney itself is determined in article 30 paragraph (2) of Law No. 16 of 2004 concerning the Prosecutor's Office (Law on the Prosecution) in the city and state administration sector.

According to Article 30 paragraph (2) of the Prosecution Constitution, prosecutors who represent the state to recover state losses must first be based on a superior power of attorney from the injured government agency or agency. [5] These legal provisions indicate that the prosecutor, as a representative of the state or a representative of the government before the District Court, High Court or Supreme Court even outside the court, can represent the government or the state as a party to the plaintiff defendant [6].

One of the legal actions in order to save state losses by the State Attorney General was when the North Lampung District Attorney sued the heir (late) Amiruddin Is, S.E, who was a salaried officer at the Agriculture and Livestock Service Office of North Lampung Regency.

Previously, based on the results of investigations carried out by the North Lampung District Attorney's Office investigators of alleged corruption in the implementation of Employee Salary Expenditures at the Agriculture and Livestock Service Office of North Lampung Regency for Fiscal Year 2012 and Fiscal Year 2013 and based on the Audit Result Report of the Republic of Indonesia Audit Agency Representative Lampung Province Number :31/LHP/XVIII.BLP/2014 August 22, 2014, it was clear that there was a state loss due to the actions of the convicted person Supriyanta. S.E., M.M. with (late) Amiruddin Is, S.E. in the amount of Rp. 1,358,938,746.00, (one billion three hundred fifty-eight million nine hundred thirty-eight thousand seven hundred and forty-six rupiah).

Investigators at the North Lampung District Prosecutor's Office have also legally confiscated one original certificate in the name of Amiruddin Is, S.E., dated May 14, 2014. They have received approval from the Kotabumi District Court based on the stipulation number: 246/Pen.Pid/2014/PN/Kbu. However, while still being investigated, Amiruddin Is, S.E., passed away.

Referring to Article 33 of UU PTPK, the investigator will immediately submit the case files of the Investigation Results to the State Attorney or the aggrieved agency to file a civil suit against his heirs with the Kotabumi Religious Court Decision Number 0088/Pdt.p/ 2015/PA.Ktbm October 20, 2015.

The State Attorney at the North Lampung District Prosecutor's Office finally sued the heirs (defendant and co-defendant) [7] to the Kotabumi District Court on April 19, 2017. Based on the results of the examination by the Kotabumi District Court, the defendants and co-defendants were convicted of paying compensation for the Government's losses. North Lampung area of Rp. 340,843,750 (three hundred forty million eight hundred and thirty-four thousand seven hundred and fifty rupiahs) jointly and severally punishing the defendants and co-defendants.

Based on the description above, the problems to be examined in this study are as follows:

1. What is the authority of prosecutors as state lawyers in recovering state losses to the heirs of perpetrators of corruption?

2. What is the role of the state attorney's attorney in the civil suit process against the heirs of the perpetrators of corruption?

\section{Research Method}


This type of research is normative-empirical research with descriptive research type. [8] The approach to the problem used is the applied normative (applied law approach). The data used are primary in this study obtained by the interview method. Observations are used to clarify the required data and secondary data from primary legal materials and secondary materials. This research using a qualitative data analysis.

\section{Discussion}

\subsection{The Authority of Attorneys as State Attorneys in Returning State Losses to Heirs of Corruption Crimes}

The North Lampung District Prosecutor's Office has investigated the case on Supriyanta's behalf. S.E., M.M. as the operator of the salary for the North Lampung Regency Financial and Asset Management Agency and the late Amiruddin Is, S.E. as pay officer for the salary of the North Lampung Regency Agriculture and Livestock Service for alleged corruption in the implementation of Employee Salary Expenditures at the Agriculture and Livestock Service Office of North Lampung Regency for the 2012 fiscal year and 2013 fiscal year. BPK RI) representatives of Lampung Province issued an examination result report Number: 31/LHP/XVIII.BLP/2014 which stated that there had been obvious state losses resulting from Supriyanta's actions. S.E., M.M., and Amiruddin Is, S.E.

The Republic of Indonesia Supreme Audit Agency, representative of Lampung Province, calculated the state's losses amounting to Rp. 1,358,938,746.00 and deducted for 10\% IWP, Housing Savings, Health Insurance, and Income Tax of Rp. 157,269,246.00 so that Supriyanta must replace the state financial losses. S.E., M.M., and Amiruddin Is, S.E. amounting to Rp. $1,201,669,500,-$.

During the investigation process, Amiruddin Is, S.E., returned the proceeds of corruption to the state treasury through Bank Lampung in the amount of Rp. 260,000,000.00. However, during the investigation process, Amiruddin Is, S.E., died. Evidenced by a Death Certificate Number: 883/872.a/23-LU/I.3/2014.

Investigations against other suspects, namely Supriyanta, S.E., M.M. still implemented. Even though one of the suspects has passed away, the North Lampung District Prosecutor's Office transferred the case to the Corruption Court at the Tanjung Karang District Court.

The death of Amiruddin Is, S.E., was a legal event that had legal consequences, namely the emergence of inheritance rights on the heirs. As formulated in Article 830 of the Civil Code, the legal basis for inheritance is "Inheritance only takes place because of death," meaning that it can be understood that a person who has passed away all rights, including obligations, are transferred to his heirs. As for the rights and obligations that are transferred to the heirs, namely the scope of ownership of assets or rights and obligations that can be valued in money [10].

Related to the death of a suspect in a criminal act of corruption, Article 33 of the PTPK Act instructs investigators to immediately submit the case files resulting from the investigation to the State Attorney or the aggrieved agency to file a civil suit against the heirs [11].

Article 32 of the PTPK Act in its explanation, states that the order to submit the case files can only be carried out if "there has been a loss in state finances," that is, the amount of loss that has been calculated is based on the findings of the authorized institution or appointed public accountant. In this corruption case, BPK RI representatives from Lampung Province.

The heir of the late Amiruddin Is, S.E., was known by the North Lampung District Attorney through the Kotabumi Religious Court Decree Number: 0088/Pdt.p/2015/PA.Ktbm [12] which states that the heirs of the late Amiruddin Is, S.E., consists of a wife and 4 (four) children.

In connection with the forms of authority of the State Attorney's Office in resolving civil and state administrative cases, Article 30 of the Law on the Prosecution establishes four powers, namely, 1. Law enforcement; 2. Legal Aid; 3. Legal Services; and 4. Legal Considerations [4].

Before carrying out a task, each Implementing Unit is required to do a review to find out [13] whether the Attorney General has the authority to provide Legal Aid, Legal Considerations, Law Enforcement or Other Legal Actions or Will DATUN not have any conflicts of interest in carrying out its duties, functions, and authority with other fields?

Based on the authority regulated by the Constitution on the Prosecutor's Office, in resolving the case of the late Amiruddin Is, SE, State Attorney has carried out two forms of authority in the 
form of providing legal assistance in the civil sector to the Regional Government of North Lampung Regency to act as the attorney for the case in the case. civil rights at the Kotabumi District Court by suing the heir of the late Amiruddin Is, SE, based on a Special Power of Attorney Number: B-665/N.8.13/Gtn/03/2017 and a Special Power of Attorney for Substitution Number: B$3205 / \mathrm{N} .8 .13 / \mathrm{Gtn} / 10 / 2017$, and law enforcement authorities. [14] Civil litigation in a criminal act of corruption is also a law enforcement process carried out by the Prosecutor's Office represented by the State Attorney.

The authority of the State Attorney is in line with the Attorney General's Regulation Number: PER-025/A/JA/11/2015, which states that the formation of the Junior Attorney General for Civil and State Administration (JAM DATUN) work unit is to play a role in saving and recovering finances and assets of the country [13].

\subsection{The Role of State Attorneys in the Civil Law Suit Process against the Heirs of Corruption Crimes}

The authority of State Attorneys in law enforcement is to recover state financial losses. State Attorneys Attorneys can represent the state as a plaintiff or a defendant. The approach taken by the State Attorney General in recovering state losses is no longer like a public prosecutor. The prosecutor can resolve the case through non-litigation channels before making a lawsuit to court.

As the attorney for the North Lampung regency government, the State Attorney General has contacted and invited the heirs three times to settle state losses deliberately. However, because there is no clarity and good faith with a superior power of attorney from the Head of the North Lampung District Prosecutor's Office, the State Prosecutor has submitted his lawsuit to the Kotabumi District Court.

The State Attorney General formulated a civil suit against the heir of the late Amiruddin IS, S.E., based on a lawsuit against the law, including:

1. State that the late Amiruddin Is, S.E., had committed an act against the law.

2. Sentencing the late Amiruddin Is, S.E., or his heirs to pay a replacement fee of Rp. $340,834,750$,

Lawsuits the Act against the law against heirs of the late Amiruddin Is, S.E., do not mean that the heirs committed an illegal act. However, Gatra Yudha Utama, a prosecutor at the Kotabumi District Attorney, said that "The prosecutor believes that the assets resulting from the actions of the late Amiruddin Is, S.E., which caused the heirs enjoyed financial losses. So that those who control the assets of the proceeds of corruption are the heirs.

The State Attorney also used the decision of the Corruption Court at the Tanjung Karang District Court Number: 54/Pid.Sus-TPK/2014/PN.Tjk which stated that the late Amiruddin Is, S.E., and his friend Supriyanta S.E., M.M legally and convincingly committed a criminal act of corruption as the basis for an action against the law. However, according to the author, another legal basis can be imposed on the heirs.

The legal basis is Article 1100 of the Civil Code, which confirms the obligations of the heirs to pay the debts of the heirs, and Article 1367 of the Civil Code, which confirms the responsibility for action against the law because of the people under his control or the property under his control.

Procedures or procedures for recovering state financial losses through the civil suit in criminal acts of corruption are carried out in line with civil procedural constution [15].

1. The State Attorney includes the decision of the Corruption Court at the Tanjung Karang District Court Number: 54/Pid.Sus-TPK/2014/PN.Tjk as evidence that the late Amiruddin Is, S.E., together with Supriyanta, S.E., M.M., had committed a criminal act of corruption.

2. The State Attorney presented Supriyanta, S.E., M.M., as a witness who testified that he and the late Amiruddin Is, S.E., had indeed committed a criminal act of corruption and, at the stage of the investigation, had also jointly returned some of the state's losses due to this act.

3. The state attorney also includes evidence of a certificate of money depositing into the state treasury through Bank Lampung, which was deposited by the late Amiruddin Is, S.E., during the investigation process.

Kotabumi District Court in case No.: 4/Pdt.G/2017/PN.Kbu granted part of the lawsuit of the State Attorney General's Office. The Panel of Judges decided that the late Amiruddin Is, S.E., had acted against the law and punished the heirs, namely Defendant I and Defendant II, to pay compensation for the state losses of the North Lampung Regency Government of Rp. 
$340,834,750.00$ - jointly and severally. Besides, the Panel of Judges rejected the Plaintiff's claim for the rest.

The role of the prosecutor as a State Attorney in the civil court process is completed when the court decision is read and has permanent legal force.

The execution of civil decisions is different from the execution of criminal decisions. The court's civil decisions' execution is carried out through bailiffs, while the public prosecutor executes criminal decisions. This explains that there are differences in the role of prosecutors in public law and prosecutors in the realm of private law. In public law, the prosecutor has a role as an investigator, investigator, and public prosecutor. In contrast, in the realm of private law, the prosecutor has the role of a state lawyer who represents the state outside and inside the court, both as plaintiff and defendant.

\section{Conclusion}

Based on the description of the discussion, the authors can conclude this study as follows:

1. State Attorneys have the authority to provide legal assistance to the Regional Government of North Lampung Regency to sue the heirs of the late Amiruddin Is, S.E., to recover state losses. This authority is regulated in Article 30 of the Law on the Prosecutor's Office, Article 18 Paragraph (1) letter b and Articles 32, 33, 34 of Law Number 31 of 1999 in conjunction with Law Number 20 of 2001 concerning the Eradication of Corruption Crimes.

2. The role of prosecutors in private law is as state attorneys who represent the state outside and in court both as plaintiffs and defendants based on a superior attorney's power. As a party to a civil case, the State Attorney General is also subject to the civil procedural law provisions in force in Indonesia.

State Attorney in Indonesia has the authority to provide legal assistance, to carry out law enforcement and role of state attorneys who represent the state outside and in court both as plaintiffs and defendants based on a superior power of attorney. The authority and role of the State Attorney General's Office can be identified by reviewing the Kotabumi District Court Decision Number: 4/Pdt.G/2017/PN Kbu.

\section{References}

[1] A. Hamzah, Korupsi di Indonesia: Masalah dan Pemecahannya. Jakarta: Gramedia Pustaka Utama, 1984.

[2] ................, Pemberantasan Tindak Pidana Korupsi. Undang-Undang Nomor 20 Tahun 2001.

[3] F. Munir, Perbuatan Melawan Hukum. Bandung: Citra Aditya Bakti, 2002.

[4] …............, Kejaksaan RI. Undang-Undang Nomor 16 Tahun 2004.

[5] S. Mertokusumo, Hukum Acara Perdata, Edisi VIII. Yogyakarta: Liberty, 2002.

[6] ................, Pengarahan Jaksa Agung Muda Perdata Dan Tata Usaha Negara. Raker Kejaksaan.

[7] J. Lemek, Penuntun Membuat Gugatan. Yogyakarta: Liberty, 1993.

[8] A. Muhammad, Hukum dan Penelitian hukum. Bandung: Citra Aditya Bakti, 2004.

[9] R. I. M. Agung, Pedoman Pelaksanaan Tugas dan Administrasi Pengadilan, Buku II. Jakarta: Mahkamah Agung RI, 1994.

[10] S. Soedaryo, Kitab Undang-undang Hukum Perdata (KUHPdt), cet ke 14. Jakarta: Sinar Grafika, 2016.

[11] ................, Standar Operasional Prosedur Pada Jaksa Agung Muda Bidang Perdata dan Tata Usaha Negara. Peraturan Jaksa Agung RI Nomor: PER-018/JA/07/2014.

[12] M. Y. Harahap, Kedudukan Kewenangan dan Acara Peradilan Agama: UU No. 7 tahun 1989, Edisi II. Jakarta: Sinar Grafika, 2007.

[13] ................ Petunjuk Pelaksanaan Penegakan Hukum, Bantuan Hukum, Pertimbangan Hukum, Tindakan Hukum Lain Dan Pelayanan Hukum Di Bidang Perdata Dan Tata Usaha Negara. PER025/A/JA/11/2015.

[14] R. Rambe, Hukum Acara Perdata Lengkap. Jakarta: Sinar Grafika, 2003.

[15] M. Y. Harahap, Hukum Acara Perdata Tentang Gugatan, Persidangan, Penyitaan, Pembuktian, dan Putusan Pengadilan. Jakarta: Sinar Grafika, 2005. 